Review began $07 / 27 / 2021$ Review ended 10/04/202 Published 10/17/2021

(๑) Copyright 2021 Nso et al. This is an open access article distributed under the terms of the Creative Commons Attribution License CC-BY 4.0. which permits unrestricted use, distribution, and reproduction in any medium, provided the original author and source are credited.

\section{Cannabis and Its Potential Protective Role Against Inflammatory Bowel Disease: A Scoping Review}

Nso Nso ${ }^{1}$, Akwe Nyabera ${ }^{2}$, Mahmoud Nassar ${ }^{3}$, Mohsen S. Alshamam ${ }^{3}$, Vikram Sumbly ${ }^{3}$, Mallorie Vest ${ }^{1}$ , Nehal Patel ${ }^{4}$, Gilbert Ojong ${ }^{5}$, Vincent Rizzo ${ }^{1}$

1. Internal Medicine, Icahn School of Medicine at Mount Sinai, Queens Hospital Center, New York, USA 2. Internal Medicine, New York City Health and Hospitals/Oueens, New York, USA 3. Internal Medicine, Icahn School of Medicine at Mount Sinai, New York City Health and Hospitals/Queens, New York, USA 4. Internal Medicine, Chicago Medical School, Chicago, USA 5. Internal Medicine, La Magna Health/United Regional Hospital, Atlanta, USA

Corresponding author: Vikram Sumbly, vikram.sumbly@gmail.com

\begin{abstract}
Globally, around $15 \%-40 \%$ of patients suffering from inflammatory bowel disease (IBD) use Cannabis for pain reduction, increased appetite, and reduced need for other medications. Although many patients report having benefited by using Cannabis in IBD, there is still a lack of consensus regarding the use of Cannabis in IBD. The aim is to identify, explore and map literature on the potential protective role of Cannabis against IBD through this scoping review. Preferred Reporting Items for Systematic Reviews and Meta-Analyses (PRISMA) guidelines were followed during the search to answer the focal question: (1) Does Cannabis play a protective role against IBD as assessed by clinical remission; (2) If yes, what is the mechanism of action for this protective role. There were only three randomized controlled trials (RCTs) and three observational studies that satisfied the selection criteria of this scoping review. Although promising results including the improvement in general well-being/ Harvey-Bradshaw Index, health perception enhancement $[4.1 \pm 1.43$ to $7 \pm 1.42$ ( $p=0.0002)$, weight gain, Crohn's Disease Activity Index (CDAI) score $<150$, Mayo scores (4-10), and reduction in clinical complications have been found in some studies, its medical use in IBD is still questionable due to the lack of high-quality evidence. Future RCTs studies should determine the cannabis treatment parameters and validate its safety and effectiveness in the IBD setting. The highlights include: the current literature provides inconclusive evidence concerning the protective role of cannabis for IBD patients; limited research evidence regarding the therapeutic use of cannabinoids for IBD warrants future investigation via RCTs; cannabis provides some benefits to IBD patients by improving their general wellbeing perceptions, Harvey-Bradshaw Index, Mayo scores, and minimizing their clinical complications.
\end{abstract}

Categories: Internal Medicine, Gastroenterology

Keywords: cannabis science, ibd, internal medicine, preventative medicine, pain management

\section{Introduction And Background}

Inflammatory bowel disease (IBD) is a multifactorial gastrointestinal (GI) disease that causes chronic intestinal inflammation. Various predisposing factors of IBD include host genetics [1], uncontrolled inflammation due to dysregulated immune response to dietary antigens [2], exogenous factors such a4s western- diet based on high-fat dairy products, animal products, prepackaged food items, and processed meat [3], epithelial barrier defects [4] and gut-microbes [5]. These factors are found to play a crucial role in IBD. The major subtypes of IBD are Ulcerative colitis (UC) and Crohn's disease (CD). IBD usually presents as with symptoms such as abdominal pain, diarrhea, rectal bleeding, and weight loss [6] which is reported as an exaggerated response against microbial antigens. These changes cause structural damage of the intestinal mucosa in patients with a familial predisposition.

Various treatment modalities, including anti-inflammatories (aminosalicylic acid (5-ASA) and corticosteroids), immunosuppressants (azathioprine, and methotrexate) have been used to manage IBD. Biological agents such as antitumor necrosis factor (TNF)-a antibodies, vedolizumab (anti-a4b7 integrin antibody) and ustekinumab (interleukin [IL]-12/IL-23 antibody) have also been used to treat severe forms of IBD. Many of these treatment methods have been reported to have side effects such as opportunistic infections, malignancies, and infusion/injection reactions [7]. Hence, complementary and alternative medicine such as treatment with prebiotics, vitamins, probiotics, high-fiber diets, among others are becoming more popular. One such potential therapeutic choice is Cannabis sativa (CS) or its derivatives $[8,9]$.

Cannabis is obtained from the Cannabis sativa plant. $\Delta$ 9-tetrahydrocannabinol (THC) and cannabidiol (CBD) are among the most reported cannabinoids (active phytochemicals) that can activate endogenous Cannabinoid Receptors 1 (CB1) and 2 (CB2). The endocannabinoid system (ECS) contributes to gut hemostasis and comprises numerous endogenous receptors that regulate mucosal permeability and the gut microbiota that often triggers IBD following the loss of immunological tolerance. The ECS targets are the classic cannabinoid receptors (CB1 and CB2) and are known for its antinociceptive, anti-inflammatory, antidiarrheal, antiemetics and analgesic effects. While Cannabis has been used vastly for various conditions such as rheumatic pain, constipation, its use has not been entirely legalized due to the tendency to develop a 
dependency, and cause abuse. Epidiolex ${ }^{\circledR}$ and Sativex ${ }^{\circledR}$ are among the first FDA-approved cannabis-based drugs to treat seizures, multiple sclerosis and cancer pain. Around $15-40 \%$ of patients [10], suffering from inflammatory bowel disease (IBD) use Cannabis for pain reduction, increasing appetite, and reducing the need for other medications [11]. Although many patients report having benefited by using Cannabis in IBD, there is still a lack of consensus regarding the use of Cannabis in IBD [12]. The medical literature does not specify any age-specific criteria for cannabis use for IBD due to the safety concerns based on a high risk of its potential abuse. Therefore, the main objective for the proposed scoping review is to identify, explore and map literature on the potential protective role of Cannabis against IBD as assessed by clinical remission.

\section{Review \\ Methodology}

We included observational, retrospective and prospective studies, as well as randomized controlled trials (RCTs) published in English from January 2010 to December 2020. "Ulcerative Colitis" or "Crohn's Disease" or "Inflammatory Bowel Diseases" or "colitis"; and "Cannabis sativa" or 'cannabinoids" or "THC" or "cannabidiol" were the MeSH terms used in combination. PubMed/Medline, PMC, EMBASE, and Cochrane databases that were extensively searched.

The focal question used for this review was: (1) Does cannabis play a protective role against IBD as assessed by clinical remission; (2) If yes, what is the mechanism of action for this protective role". To answer these questions, the PRISMA guidelines were followed during the search and selection. A review protocol was prepared, but since this is not a systematic review, it was not registered in PROSPERO. E7ligibility criteria were decided before the commencement of the study. Study characteristics were identified based on population (patients belonging to any gender and age group with UC and CD who were treated with cannabis/cannabinoids); Intervention (cannabis/cannabinoids); Control (with or without placebo) and Outcome (improvement as measured by clinical remission).

Two hundred and sixty-four articles published between 2011 and 2019 were initially screened based on the study title. The screening included RCTs and observational studies; however, meta-analyses, systematic reviews, scoping reviews, editorials, and opinion papers were summarily excluded from the review process8,9. Fifty-four duplicate articles were removed by two independent reviewers while ensuring the inter-rater reliability. Thirty-five full-text articles were further screened to evaluate their applicability for this scoping review. Six studies were finally selected to analyze the protective role of cannabis against IBD.

\section{Source Selection}

Titles and abstracts obtained from the electronic bibliographic database search were screened for potential eligibility by two reviewers. Full texts were downloaded only for those studies which met the eligibility criteria. A training exercise was conducted for the reviewers and highly satisfactory ( 0.8 and above) kappa score was obtained to ascertain high inter-rater reliability. The guidelines given in the Cochrane handbook for systematic reviews were used to give direction to the discussion. Data was extracted from reports independently by two reviewers into an excel sheet. Disagreements between the reviewers were evaluated, discussed, and resolved by two other reviewers. The variables sought in these data included any mention of the gastro-protective role of Cannabis in cases of IBD.

The search results were screened independently by either of the two reviewers. Quality appraisal and risk of bias assessment was not done in this study as this is a scoping review. The aim was to map all available recommendations regarding the protective role of Cannabis against IBD. The principal summary measures included all details of the protective action of Cannabis in IBD. Since only a few RCTs of cannabinoids have been published, we included recent review articles on this topic to identify the research gap and map available literature.

\section{Results}

Study Objectives

Six studies were included. These were aimed at describing the effects of Cannabis in CD [13], assessing whether treatment with inhaled Cannabis improves the quality of life, reduces disease activity and promotes weight gain [14]. As well as determining whether Cannabis can induce disease remission in patients with Crohn's disease [15], the effects of cannabidiol on Crohn's disease [16], evaluation of efficacy, safety and tolerability of CBD-rich botanical extract in ulcerative colitis (UC) [17] and assessing the prevalence of complications arising due to Crohn's disease among cannabis users and non-users [18]. While some authors considered only one type of IBD, i.e., CD [15,16,18] or UC [17], Lahat et al. 2012 considered both UC and CD.

Age

The mean age of the participants ranged from $34 \pm 11.4$ to $44 \pm 10.7$. A total of 100 patients (68 males and 32 females) were recruited in three RCTs (a minimum of 19 and a maximum of 60 participants). Among the observational studies, the largest number of patients $(n=615)$ were seen in a retrospective cohort study by Mbachi et al. and the least number of patients $(n=13)$ were reported in the study by Lahat et al. 


\section{Cureus}

Type of Study

The included studies had different study designs. These were retrospective observational [13], open-label prospective single-arm trial [14], retrospective cohort study [18] and three randomized placebo-controlled trials $[15,16,17]$. All three RCTs were double-blinded. Only two studies $[15,17]$ described the statistical power of the study as $80 \%$, and only Naftali et al. 2017 mentioned the number of dropouts.

Disease Activity Index

The inclusion criteria of these studies were heterogeneous. Different disease activity indices for IBD were considered in these studies, such as Harvey-Bradshaw Index and general well-being-VAS [13], HarveyBradshaw Index; Partial Mayo Score based on the appearance of the intestinal mucosa [14], Crohn's Disease Activity Index (CDAI) scores $>200$ who did not respond to other treatment $[15,16]$ and Mayo scores of $4-10$ in endoscopy scores $\geqslant 1[17]$. Harvey Bradshaw Index is used for collecting clinical data related to CD using five clinical parameters, while Mayo score is to assess disease activity of UC based on bowel motions and presence of visible blood in it.

Cannabis Dose

Varying doses and forms of Cannabis were used in these studies. Cigarettes containing 50 gm dry-processed plant per month [14], cigarettes with $0.5 \mathrm{~g}$ of dried cannabis flowers equivalent to $11.5 \mathrm{mg}$ THC [15], a low dose of CBD oil with $10 \mathrm{mg}$ of oil containing $5 \mathrm{mg} / \mathrm{ml}[16]$ and hard gelatin capsules containing $50 \mathrm{mg}$ CBDrich botanical extract in excipients [17]

Mode of Administration

Most of these patients were prescribed cannabis inhalation/smoke [13,15], while others took it through water-bong [13] or orally [16, 17]. The average duration of treatment with Cannabis ranged from 8 weeks to 2.12 years.

Placebo

The placebo used in the three RCTs were cannabis flower content from which the THC had been extracted [15], olive oil [16] and capsules containing excipients only [17].

Primary Endpoint

There were many primary endpoints such as a reduction in disease activity and the reduced need for surgery [13], improvement in health perception, and (quality of life) QoL [14] induction of disease remission as measured by a CDAI score of 150 or less after eight weeks of cannabis treatment [15], CDAI reduction of 70 points from week 0 to week 8 [16], increase in the percentage of patients in remission after treatment [17] and reduction in active fistulizing disease and intra-abdominal abscess [18].

\section{Secondary Endpoint}

Statistically significant improvements in social functioning; ability to work; decreased bodily pain and depression; improved weight gain and BMI, and reduction in average Harvey-Bradshaw index [14], response rate as determined by a 100 point reduction of CDAI; reduction of at least $0.5 \mathrm{mg}$ in CRP; and improvement in quality of life of at least 50 points, as measured by the Short form health survey (SF-36) [15], any adverse events within the treatment time frame of 8 weeks; ability to wean off steroids in patients, and reduction in at least $1 \mathrm{mg} / \mathrm{dl}$ in the CRP level [16], reduction in inflammatory marker levels such as blood C-reactive protein (CRP), plasma interleukin -2 and IL-6, tumor necrosis factor-alpha, and fecal calprotectin, inflammatory bowel disease questionnaire (IBDQ) score; physician global assessment of illness severity (PGAS) score; stool frequency and rectal bleeding on 4-point numerical rating scales (NRS); pain 0-10 NRS score; Mayo score and increase in body weight (Irving 2018), stricture complicating bowel disease; bowel obstruction; anemia; transfusion of blood products; parenteral nutrition requirement; small bowel resection; small bowel anastomosis, and partial or total colectomy [18].

\section{QoL Improvement}

Improvement in SF-36 Health Survey and EQ-5D Health Survey [14], a significant increase in quality of life as assessed by SF-36 [15], no withdrawal symptoms when stopping treatment at the end of the study [16] and patient-reported quality of life, as measured using the IBDQ and SGIC assessments improved in both groups but more in CBD group [17].

Adverse Effects

Only one study reported adverse effects in detail. More GI-related adverse effects, indicative of UC 
worsening, were seen in patients taking placebo [17]. Lahat et al. mentioned that patients did not report any adverse effects that affected their ability to work while using cannabis [14].

Smoking Cessation

Only Naftali et al. reported smoking cessation in some patients [13]. Of the 16 smokers who were included in the study, 3 stopped smoking before taking Cannabis. Among them, one showed significant improvement (Harvey Bradshaw score changed from 11-2), one showed slight improvement (HB score 9-7) and the last one showed no improvement (HB score of 4 before and after treatment).

\section{Statistical Analysis Used}

Only patient characteristics and medical treatment list administered before and after the cannabis use were reported by Naftali et al. in the observational study [13]. Lahat et al. describe the changes in the SF-36v2 health survey, EQ-5D health survey, Harvey Bradshaw, CRP and BMI before and after cannabis treatment [14]. Descriptive and interferential analysis, including T-test, Chi-square, and the Fisher test, describe the demographic data, past and current medical treatment, and laboratory tests (Hemoglobin, HCT, WBC and CRP). Side effects were reported by Naftali et al. 2013 and Naftali et al. 2017 in their RCTs [15,16]. Both intention-to-treat (ITT) and per-protocol (PP) analysis were reported by Irving et al. in these RCTs [17].

In the study by Mbachis et al., Student's t-test, Wilcoxon rank-sum test, or Kruskal-Wallis test were used to compare the continuous variables in cannabis users with non-users while Chi-square test or Fisher's exact test was used to compare categorical variables [18]. Multivariable logistic regression analyses were done to evaluate clinical outcome as the dependent variable and cannabis use as the explanatory variable. A propensity score match was conducted by developing a model to predict cannabis use. The statistical assessments performed by the included studies signified the reliability of their results and helped minimize the risk of bias and confounded outcomes. The comprehensive assessment of these methods guided this scoping review and helped produce valid outcomes from the contemporary literature.

\section{Case Studies}

The significant findings of these studies were the improvement in Harvey-Bradshaw Index and general wellbeing based on visual analogue scale (VAS) [13], statistically significant improvement in QoL and health perception $(4.1 \pm 1.43$ to $7 \pm 1.42(\mathrm{p}=0.0002)$, disease activity and improvement in weight [14], complete remission in 5/11 cases with a CDAI score<150 [15], CDAI levels dropped both groups. NS [16], Patients were less tolerant of CBD-rich botanical extract compared with placebo [17] and the fact that cannabis users were less likely to have the active fistulizing disease and intraabdominal abscess; blood product transfusion; colectomy and parenteral nutrition requirement [18].

In the study by Naftali et al. 2011, all patients reported improvement in their general wellbeing. It was reflected by the positive change in the VAS score from 3.1 to 7.3 on a scale of 0 (very poor wellbeing) to 10 (excellent wellbeing) [13]. The Harvey-Bradshaw index (HBI) showed a drastic reduction from $14 \pm 6.7$ to $7 \pm 4.7$, and the average number of bowel movement reduced from 8 to 5 per day. An interesting phenomenon of steroid-sparing also was seen in this study, as only four patients required steroids at the end of the study instead of 26 in the beginning.

Similar positive results were seen in the study by Lahat et al. [14]. Following treatment with cannabis cigarettes (50 g dry-processed plant per month), all the 13 patients included in the study perceived better general health, which was statistically significant $(p=0.001)$. Other parameters that showed simultaneous improvement was social functioning $(\mathrm{p}=0.0002)$, ability to work $(\mathrm{p}=0.0005)$, reduction in body pain $(\mathrm{p}=$ $0.004)$ and depression $(\mathrm{p}=0.007)$. An average increase of $4.3 \pm 2 \mathrm{~kg}$ was observed during treatment $(\mathrm{p}=$ $0.0002)$, and an increase in BMI of $1.4 \pm 0.61$ ( $\mathrm{p}=0.002$ ) was also noticed. Reduction in the average HarveyBradshaw index (indicative of disease activity) from $11.36 \pm 3.17$ to $5.72 \pm 2.68(p=0.001$ ) was also achieved. Inflammatory markers were recorded only in 6 patients. It was found that during treatment, the CRP levels returned to the normal range.

Naftali et al. found that when Cannabis was administered in the form of cigarettes containing $11.5 \mathrm{mg}$ of tetrahydrocannabinol (THC), complete remission with a CDAI score of 100 was observed in 10/11 subjects in the cannabis group ( $90 \%$; from $330 \pm 105$ to $152 \pm 109$ ) and $4 / 10$ in the placebo group (40\%; from $373 \pm 94$ to $306 \pm 143 ; p=0.028$ ) which is indicative of disease remission. Weaning from steroid dependency (3/11), better appetite and sleep, with no significant side effects were reported in the cannabis group. Furthermore, a significant increase in quality of life, decreased physical pain, improved appetite and higher satisfaction from the treatment without any significant blood count changes, CRP or liver and kidney function were also reported. One interesting finding was that none of the patients complained of any withdrawal symptoms when cannabis use was discontinued at the end of the study [15].

However, Naftali et al. found that cannabinol (CBD) was safe but had no beneficial effect in managing moderately active Crohn's disease with a Crohn's disease activity index (CDAI) 200 or more. There was a decrease in the average CDAI following cannabidiol consumption from $337 \pm 108$ to $220 \pm 122$ in the CBD 
group and $308 \pm 96(\mathrm{p}=\mathrm{NS})$ to $216 \pm 121$ in the placebo groups, respectively. No side effects or changes in the Hemoglobin, albumin, and kidney and liver function tests were observed [16].

Irving et al. found that patients on CBD-rich botanical extract were less tolerant than placebo and showed less compliance with the protocol. A subjective evaluation showed more significant improvement in the CBD group regarding patient-reported quality-of-life outcomes $(p=0.065$ and overall improvement $(p=0.003)$. Adverse events (AEs) were reported in both groups, with a more significant proportion of GI-related adverse effects in the placebo group indicative of UC worsening, probably due to the $\Delta 9$-tetrahydrocannabinol content. Mild to moderate dizziness and somnolence were the most common treatment-related AE and was observed more in patients taking CBD-rich botanical extract. However, adverse effects of the abdominal area were found to be more magnified in the control group (42\%) than in those in the test group (10\%) [17].

Mbachi et al. show an association between the use of Cannabis and improvement in many of the commonly documented complications of $\mathrm{CD}$, such as active fistulizing disease and intraabdominal abscess, blood product transfusion, colectomy, and parenteral nutrition requirement [18]. The results of this study are interpreted, taking into account the many confounding factors that could be present (Tables 1,2).

\begin{tabular}{|c|c|c|c|c|c|c|c|c|c|c|c|}
\hline $\begin{array}{l}\text { SI } \\
\text { no }\end{array}$ & $\begin{array}{l}\text { Author } \\
\text { and } \\
\text { year }\end{array}$ & Aim & $\begin{array}{l}\text { Type of } \\
\text { IBD }\end{array}$ & $\begin{array}{l}\text { Mean } \\
\text { age } \\
\text { (years) }\end{array}$ & $\begin{array}{l}\text { Sample } \\
\text { size } \\
\text { (M/F) }\end{array}$ & $\begin{array}{l}\text { Disease } \\
\text { activity } \\
\text { Index }\end{array}$ & CBD dose & $\begin{array}{l}\text { Mode of } \\
\text { administration }\end{array}$ & Placebo & $\begin{array}{l}\text { Treatment } \\
\text { duration }\end{array}$ & Results \\
\hline 1 & $\begin{array}{l}\text { Naftali } \\
\text { et al. } \\
2011 \\
{[13]}\end{array}$ & $\begin{array}{l}\text { Elaborate } \\
\text { effects of } \\
\text { Cannabis in } \\
C D\end{array}$ & CD & 36 & $\begin{array}{l}30 \\
(26 / 4)\end{array}$ & $\begin{array}{l}\text { Harvey- } \\
\text { Bradshaw } \\
\text { Index; } \\
\text { General } \\
\text { wellbeing } \\
\text { index } \\
\text { using-VAS }\end{array}$ & Varying & $\begin{array}{l}\text { Most patients } \\
\text { smoked; } \\
\text { through water- } \\
\text { bong; one } \\
\text { patient- orally }\end{array}$ & $\begin{array}{l}\text { Not } \\
\text { applicable }\end{array}$ & $\begin{array}{l}\text { The } \\
\text { average } \\
\text { duration of } \\
\text { Cannabis } \\
2.12 \text { years }\end{array}$ & $\begin{array}{l}\text { Improvement } \\
\text { in Harvey- } \\
\text { Bradshaw } \\
\text { Index and } \\
\text { general well- } \\
\text { being. }\end{array}$ \\
\hline 2 & $\begin{array}{l}\text { Lahat } \\
\text { et al. } \\
2012 \\
{[14]}\end{array}$ & $\begin{array}{l}\text { Effect of } \\
\text { inhaled } \\
\text { Cannabis on } \\
\text { quality of life, } \\
\text { disease } \\
\text { activity and } \\
\text { weight gain. }\end{array}$ & $\begin{array}{l}\text { Long } \\
\text { standing } \\
\text { IBD }\end{array}$ & $\begin{array}{l}44 \pm 10.7 \\
(C D) ; \\
29.5 \pm 2.1 \\
(U C)\end{array}$ & $13(9 / 4)$ & $\begin{array}{l}\text { Harvey- } \\
\text { Bradshaw } \\
\text { Index; } \\
\text { Partial } \\
\text { Mayo } \\
\text { Score- the } \\
\text { appearance } \\
\text { of the } \\
\text { mucosa }\end{array}$ & $\begin{array}{l}50 \text { gm dry } \\
\text { cannabis } \\
\text { per month } \\
\text { when they } \\
\text { felt pain; up } \\
\text { to } 3 \\
\text { inhalations. }\end{array}$ & $\begin{array}{l}\text { Inhaled } \\
\text { Cannabis; } \\
\text { cigarettes }\end{array}$ & $\begin{array}{l}\text { No control } \\
\text { group }\end{array}$ & $\begin{array}{l}\text { Three } \\
\text { months }\end{array}$ & $\begin{array}{l}\text { Improvement } \\
\text { in quality of } \\
\text { life, disease } \\
\text { activity and } \\
\text { weight gain. }\end{array}$ \\
\hline 3 & $\begin{array}{l}\text { Naftali } \\
\text { et al. } \\
2013 \\
{[15]}\end{array}$ & $\begin{array}{l}\text { Can } \\
\text { Cannabis } \\
\text { induce } \\
\text { remission in } \\
\text { patients with } \\
\text { CD? }\end{array}$ & $C D$ & $40 \pm 14$ & $\begin{array}{l}21 \\
(13 / 8)\end{array}$ & $\begin{array}{l}\text { CDAl } \\
\text { scores } \\
>200 \text { who } \\
\text { did not } \\
\text { respond to } \\
\text { other } \\
\text { treatment. }\end{array}$ & $\begin{array}{l}\text { Cigarette } \\
\text { with } 0.5 \mathrm{~g} \\
\text { of dried } \\
\text { cannabis } \\
\text { flowers } \\
(=11.5 \mathrm{mg} \\
\text { THC) }\end{array}$ & Smoke & $\begin{array}{l}\text { Content of } \\
\text { the } \\
\text { cannabis } \\
\text { flower } \\
\text { from } \\
\text { which } \\
\text { THC had } \\
\text { been } \\
\text { extracted }\end{array}$ & $\begin{array}{l}\text { During } \\
\text { eight } \\
\text { weeks of } \\
\text { treatment } \\
\text { and two } \\
\text { weeks } \\
\text { thereafter. }\end{array}$ & $\begin{array}{l}\text { Complete } \\
\text { remission } 5 / 11 \\
\text { with a CDAI } \\
\text { score }<150 \text {. }\end{array}$ \\
\hline 4 & $\begin{array}{l}\text { Naftali } \\
\text { et al. } \\
2017 \\
{[16]}\end{array}$ & $\begin{array}{l}\text { Effects of } \\
\text { cannabidiol } \\
\text { on Crohn's } \\
\text { disease }\end{array}$ & $\begin{array}{l}\text { Moderately } \\
\text { active CD }\end{array}$ & $\begin{array}{l}39 \pm 15 \\
(C D)\end{array}$ & $\begin{array}{l}19(11 / 8) \\
\text { other } \\
\text { medical } \\
\text { illness }\end{array}$ & CDAI >200 & $\begin{array}{l}\text { CBD oil } \\
(5 \mathrm{mg} / \mathrm{ml}) \\
10 \mathrm{mg} \text { Oral } \\
(\text { Low dose) } \\
(\mathrm{n}=10 / 9)\end{array}$ & Oral & Olive oil & $\begin{array}{l}\text { Eight } \\
\text { weeks }\end{array}$ & $\begin{array}{l}\text { CDAI levels } \\
\text { dropped both } \\
\text { groups; } \\
\text { statistically } \\
\text { non- } \\
\text { significant. }\end{array}$ \\
\hline 5 & $\begin{array}{l}\text { Irving } \\
\text { et al. } \\
2018 \\
{[17]}\end{array}$ & $\begin{array}{l}\text { Efficacy, } \\
\text { safety and } \\
\text { tolerability of } \\
\text { CBD-rich } \\
\text { botanical } \\
\text { extract in UC }\end{array}$ & UC & $\begin{array}{l}18 \text { yrs or } \\
\text { older }\end{array}$ & $\begin{array}{l}60 \\
(44 / 16)\end{array}$ & $\begin{array}{l}\text { Mayo } \\
\text { scores of } \\
4-10 ; \\
\text { (endoscopy } \\
\text { scores } \geq 1 \text { ) }\end{array}$ & $\begin{array}{l}\text { Hard } \\
\text { gelatin } \\
\text { capsules } \\
\text { containing } \\
50 \mathrm{mg} \\
\text { CBD-rich } \\
\text { botanical } \\
\text { extract in } \\
\text { excipients } \\
\text { ( } \mathrm{n}=29 / 31 \text { ) } \\
\text { Cannabidiol } \\
4.7 \% \text { THC }\end{array}$ & Oral & $\begin{array}{l}\text { capsules } \\
\text { containing } \\
\text { excipients } \\
\text { only. }\end{array}$ & Ten weeks & $\begin{array}{l}\text { Patients were } \\
\text { less tolerant of } \\
\text { CBD-rich } \\
\text { botanical } \\
\text { extract } \\
\text { compared with } \\
\text { placebo. }\end{array}$ \\
\hline
\end{tabular}




\section{Cureus}

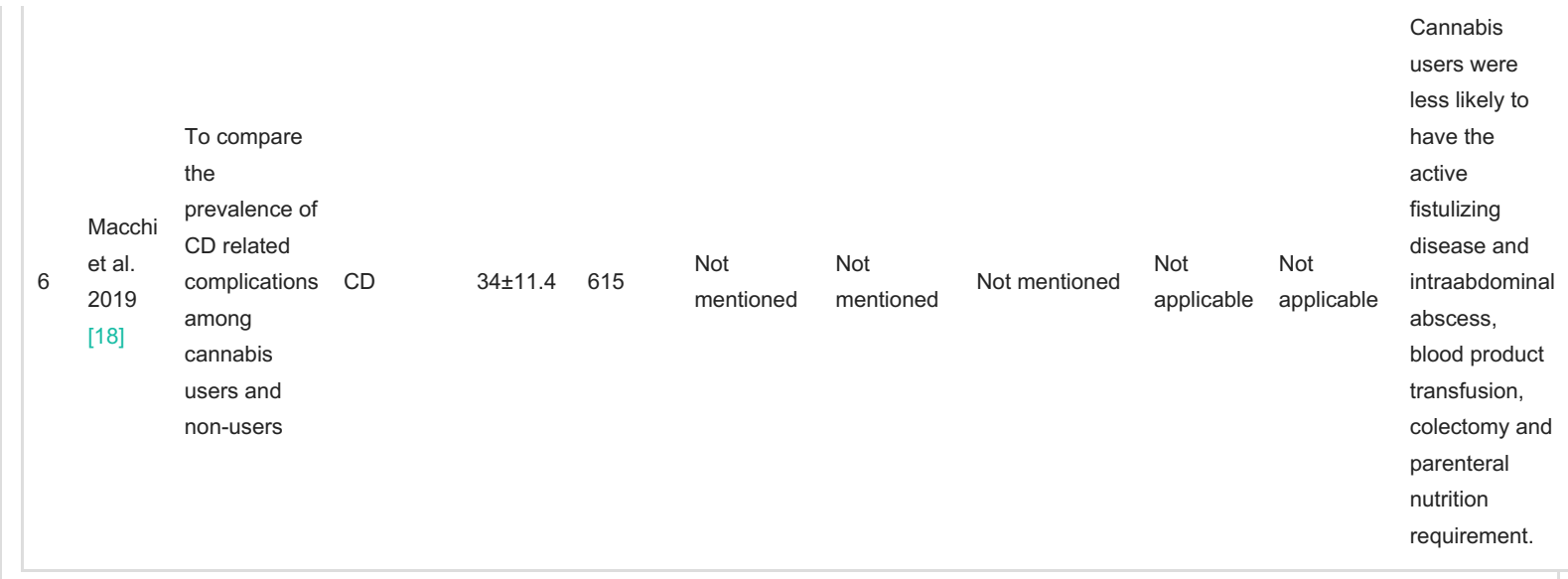

TABLE 1: Characteristics of the included study.

CD: Crohn's disease; UC: ulcerative colitis; CDAI: Crohn's disease activity index; THC: tetrahydrocannabinol.

\begin{tabular}{|c|c|c|c|c|c|c|c|c|c|c|c|}
\hline no & $\begin{array}{l}\text { Author } \\
\text { and } \\
\text { year }\end{array}$ & Type of study & Blinding & $\begin{array}{l}\text { Power of } \\
\text { study }\end{array}$ & Dropouts & Primary Endpoint & $\begin{array}{l}\text { Secondary } \\
\text { Endpoint }\end{array}$ & $\begin{array}{l}\text { QoL } \\
\text { improvement }\end{array}$ & $\begin{array}{l}\text { Adverse } \\
\text { Effects }\end{array}$ & $\begin{array}{l}\text { Smoking } \\
\text { cessation }\end{array}$ & $\begin{array}{l}\text { Analysis } \\
\text { done }\end{array}$ \\
\hline 1 & $\begin{array}{l}\text { Naftali } \\
\text { et al. } \\
2011 \\
{[13]}\end{array}$ & $\begin{array}{l}\text { Retrospective } \\
\text { observational }\end{array}$ & $\begin{array}{l}\text { Not } \\
\text { applicable }\end{array}$ & $\begin{array}{l}\text { Not } \\
\text { applicable }\end{array}$ & $\begin{array}{l}\text { Not } \\
\text { applicable }\end{array}$ & $\begin{array}{l}\text { Reduction in } \\
\text { disease activity, } \\
\text { need to surgery } \\
\text { reduced }\end{array}$ & Not applicable & $\begin{array}{l}\text { Not } \\
\text { mentioned }\end{array}$ & $\begin{array}{l}\text { None } \\
\text { reported }\end{array}$ & Yes & Descriptive \\
\hline 2 & $\begin{array}{l}\text { Lahat } \\
\text { et al. } \\
2012 \\
{[14]}\end{array}$ & $\begin{array}{l}\text { Open-label, } \\
\text { prospective, } \\
\text { single-arm trial. }\end{array}$ & $\begin{array}{l}\text { Not } \\
\text { applicable }\end{array}$ & $\begin{array}{l}\text { Not } \\
\text { applicable }\end{array}$ & $\begin{array}{l}\text { Not } \\
\text { applicable }\end{array}$ & $\begin{array}{l}\text { Improvement in } \\
\text { health perception } \\
4.1 \pm 1.43 \text { to } \\
7 \pm 1.42 \\
(p=0.0002)\end{array}$ & $\begin{array}{l}\text { Statistically } \\
\text { significant } \\
\text { improvement in } \\
\text { social } \\
\text { functioning; } \\
\text { ability to work; } \\
\text { physical pain } \\
\text { and depression; } \\
4.3 \pm 2 \text { kg during } \\
\text { treatment; and } \\
\text { an average rise } \\
\text { in BMI of } 1.4 \pm \\
0.61 . \text { The } \\
\text { average Harvey- } \\
\text { Bradshaw index } \\
\text { was reduced } \\
\text { from } 11.36 \pm 3.17 \\
\text { to } 5.72 \pm 2.68\end{array}$ & $\begin{array}{l}\text { SF-36 Health } \\
\text { Survey EQ- } \\
\text { 5D Health } \\
\text { Survey }\end{array}$ & $\begin{array}{l}\text { No } \\
\text { significant } \\
\text { adverse } \\
\text { effects } \\
\text { reported }\end{array}$ & No & $\begin{array}{l}\text { Correlationa } \\
\text { analysis }\end{array}$ \\
\hline 3 & $\begin{array}{l}\text { Naftali } \\
\text { et al. } \\
2013 \\
{[15]}\end{array}$ & RCT & $\begin{array}{l}\text { Double- } \\
\text { blinded }\end{array}$ & $80 \%$ & $\begin{array}{l}\text { Not } \\
\text { mentioned }\end{array}$ & $\begin{array}{l}\text { Induction of } \\
\text { remission, defined } \\
\text { as a CDAI score of } \\
150 \text { or less after } \\
\text { eight weeks of } \\
\text { cannabis treatment. }\end{array}$ & $\begin{array}{l}\text { Response rate, } \\
\text { determined as a } \\
100 \text { point } \\
\text { reduction of } \\
\text { CDAI, reduction } \\
\text { of at least } 0.5 \mathrm{mg} \\
\text { in CRP or } \\
\text { improvement in } \\
\text { the quality of life } \\
\text { of at least } 50 \\
\text { points, as } \\
\text { measured by the } \\
\text { Short-form } \\
\text { health } \\
\text { survey } \\
\text { (SF-36) }\end{array}$ & $\begin{array}{l}\text { Significant } \\
\text { increase in } \\
\text { quality of life } \\
\text { as assessed } \\
\text { by SF-36 }\end{array}$ & $\begin{array}{l}\text { Sleepiness, } \\
\text { nausea, } \\
\text { mild } \\
\text { memory } \\
\text { loss, } \\
\text { dizziness } \\
\text { (only in a } \\
\text { few }\end{array}$ & & $\begin{array}{l}\text { T-test, Chi- } \\
\text { square, } \\
\text { Fisher test }\end{array}$ \\
\hline
\end{tabular}




\section{Cureus}

\begin{tabular}{|c|c|c|c|c|c|c|c|c|c|c|c|}
\hline 4 & $\begin{array}{l}\text { Naftali } \\
\text { et al. } \\
2017 \\
{[16]}\end{array}$ & RCT (block) & $\begin{array}{l}\text { Double- } \\
\text { blinded }\end{array}$ & $\begin{array}{l}\text { Not } \\
\text { mentioned }\end{array}$ & One & $\begin{array}{l}\text { CDAl reduction of } \\
70 \text { points from week } \\
0 \text { to week } 8 \text {. }\end{array}$ & $\begin{array}{l}\text { Any adverse } \\
\text { events within the } \\
\text { time frame of } 8 \\
\text { weeks, the ability } \\
\text { to stop steroids } \\
\text { in patients } \\
\text { treated with } \\
\text { steroids at the } \\
\text { beginning of the } \\
\text { study, and } \\
\text { reduction in at } \\
\text { least } 1 \mathrm{mg} / \mathrm{dl} \text { in } \\
\text { the CRP level. }\end{array}$ & $\begin{array}{l}\text { QoL was } \\
\text { taken but not } \\
\text { mentioned in } \\
\text { the result }\end{array}$ & $\begin{array}{l}\text { Headache, } \\
\text { sleepiness, } \\
\text { nausea, } \\
\text { dizziness; } \\
\text { statistically } \\
\text { not } \\
\text { significant. }\end{array}$ & No & $\begin{array}{l}\text { T-test, Chi- } \\
\text { square, } \\
\text { Fisher test }\end{array}$ \\
\hline 5 & $\begin{array}{l}\text { Irving } \\
\text { et al. } \\
2018 \\
{[17]}\end{array}$ & RCT & $\begin{array}{l}\text { Double- } \\
\text { blinded }\end{array}$ & $80 \%$ & $\begin{array}{l}\text { Not } \\
\text { mentioned }\end{array}$ & $\begin{array}{l}\text { Percentage of } \\
\text { patients in } \\
\text { remission after } \\
\text { treatment }\end{array}$ & $\begin{array}{l}\text { Inflammatory } \\
\text { marker levels } \\
\text { (blood CRP, } \\
\text { plasma IL-2, IL- } \\
6 \text {, TNF-a, and } \\
\text { faecal } \\
\text { calprotectin; } \\
\text { IBDQ score; } \\
\text { PGAS score; } \\
\text { stool frequency } \\
\text { and NRS; Mayo } \\
\text { score; body } \\
\text { weight }\end{array}$ & $\begin{array}{l}\text { Patient- } \\
\text { reported } \\
\text { quality of life, } \\
\text { as measured } \\
\text { using the } \\
\text { IBDQ and } \\
\text { SGIC } \\
\text { assessments, } \\
\text { improved in } \\
\text { both groups } \\
\text { but more in } \\
\text { the CBD } \\
\text { group }\end{array}$ & $\begin{array}{l}\text { Gastro- } \\
\text { intestinal- } \\
\text { related } \\
\text { adverse } \\
\text { effects, } \\
\text { indicative } \\
\text { of UC } \\
\text { worsening }\end{array}$ & $\begin{array}{l}\text { Not } \\
\text { mentioned }\end{array}$ & $\begin{array}{l}\text { Both ITT } \\
\text { and PP }\end{array}$ \\
\hline 6 & $\begin{array}{l}\text { Macchi } \\
\text { et al. } \\
2019 \\
{[18]}\end{array}$ & $\begin{array}{l}\text { A Retrospective } \\
\text { Cohort Study }\end{array}$ & $\begin{array}{l}\text { Not } \\
\text { applicable }\end{array}$ & $\begin{array}{l}\text { Not } \\
\text { applicable }\end{array}$ & $\begin{array}{l}\text { Not } \\
\text { applicable }\end{array}$ & $\begin{array}{l}\text { Active fistulizing } \\
\text { disease and intra- } \\
\text { abdominal abscess, }\end{array}$ & $\begin{array}{l}\text { Bowel } \\
\text { obstruction, } \\
\text { anemia, } \\
\text { transfusion of } \\
\text { blood products, } \\
\text { parenteral } \\
\text { nutrition } \\
\text { requirement, } \\
\text { small bowel } \\
\text { resection, small } \\
\text { bowel } \\
\text { anastomosis, } \\
\text { and partial or } \\
\text { total colectomy }\end{array}$ & $\begin{array}{l}\text { Not } \\
\text { applicable }\end{array}$ & $\begin{array}{l}\text { Not } \\
\text { mentioned }\end{array}$ & $\begin{array}{l}\text { Not } \\
\text { mentioned }\end{array}$ & $\begin{array}{l}\text { Multivariable } \\
\text { logistic } \\
\text { regression }\end{array}$ \\
\hline
\end{tabular}

\section{TABLE 2: Characteristics of the included study (contd.).}

SF-36 Health Survey: Short form health survey; EQ-5D Health Survey: EuroQol- 5 dimension health survey; CRP: C-reactive protein; IL: Interleukin; TNF Tumor necrotic factor; IBDQ score; Inflammatory bowel disease questionnaire score; PGAS score: Physician global assessment scores; NRS: Numerical rating scale; ITT: Intention to treat analysis; PP: per-protocol analysis.

Endocannabinoids

Some of the natural cannabis compounds used for IBD are Cannabidiol (CBD), cannabigerol and cannabichromene. CBD is known to have anti-inflammatory properties without adverse psychotic effects [16]. Cannabis and its constituents act through CB1 and CB2 receptors situated in different GI system areas such as the liver, pancreas, stomach, small and large intestines. Activation of these CB1 and CB2 receptors produce antiemetic, anti-motility, and anti-inflammatory effects through inhibition of adenylyl cyclase with the reduced cAMP formation, which inhibits neurotransmitter release from a presynaptic neuron by CB1 and pro-inflammatory cytokine release by CB2 $[19,20]$. When cannabinoids bind to the prejunctional CB1 receptors, decreased gut motility and secretion occurs due to reduced excitatory neurotransmission causes [21]. Research shows that activation of CB1 receptors also helps control emesis, reduces peripheral inflammatory hypersensitivity and hyperalgesia, along with the control of centrally originating pain.

The Dependency of Cannabis in $O B D$

Dependency and potential for abuse are among the common problems associated with chronic cannabis 
users due to impairment of mental and cognitive functions. The dependency also affects the heart, lungs and psyche. Both observational and placebo-controlled studies of Cannabis in IBD did not show any substantial abuse potential, possibly because of their smaller sample size and short duration of treatment [15]. Prevalence of cannabis abuse is more in the general population than patients with IBD complaints and similarly in IBD patients compared to controls [22]. Weiss et al. reported more use of Cannabis in control subjects than patients with IBD (72.9\% vs $63 \%$ ), which could impose a higher risk of cannabis dependency in IBD patients [23]. Synergistic cannabinoids were demonstrated in a study by producing better antihyperalgesia through vanilloid TRPV1 receptors [24].

\section{Protective Effects of Cannabis against IBD}

There were three RCT and three observational studies included in this scoping review. The efficacy and protective role of Cannabis can be evaluated only through RCTs. However, this scoping review does not elaborate on the studies' risk bias, data extraction high-risk bias in most of these studies. Case definitions for IBD varied in the study. Also, we found that Naftali et al. [15] had older patients in the cannabis group than the placebo group participants. Moreover, despite the randomization of participants, several participants could have found out their treatment group due to the psychotropic effects of Cannabis [9]. In the study by Naftali in 2017 [16], more than half of the cannabis participants were smokers compared with none of the placebo participants. It should be noted that smoking is contraindicated in IBD, particularly CD, and so it would not be appropriate to advocate a smoked product. Among these, the overall risk of bias was low for the study by Irving et al. [17]. A proper sample size calculation based on the study's power done a priori is an essential step in any clinical trial. Among the included study only Naftali et al; and Irving et al. described the study's statistical power as $80 \%$, but none reported the formula used $[15,17]$.

There is no direct evidence regarding the best protective dose of Cannabis in IBD. Patients who used Cigarettes containing 50 gm dry-processed plant per month [14], did not report any adverse effects that disturbed their working ability using Cannabis. In another study by Naftali et al., although induction of CD remission was not achieved with cigarettes containing $0.5 \mathrm{~g}$ of dried cannabis flowers equivalent to $11.5 \mathrm{mg}$ THC, they concluded that THC produced a significant clinical steroid-free benefit in all but one active CD patient [15].

However, another randomized, placebo-controlled trial by Naftali et al., oral (sublingual oil droplets) $10 \mathrm{mg}$ twice daily dose of CBD in 20 moderately active CD showed no beneficial effects [17]. This could be attributed to the low doses of CBD or a lack of synergism with other cannabinoids. Recently, a Cochrane review [9] did not find any conclusive results regarding Cannabis's beneficiary role in clinical remission of $\mathrm{CD}$, which could again be due to small sample sizes in three RCTs.

Two main statistical approaches used to analyze RCT data are the intention to treat (ITT) and per-protocol (PP) analysis. At the same time, ITT analysis measures the effect of assigning a treatment, PP analysis measures receiving a treatment. Irving et al. used both these to interpret the results of their RCTs [17]. In ITT analysis, participants who drop out of the study or are not compliant to study medications are also considered in the trial's primary analysis. This method's advantages include retaining the balancing of the risk factors between the study arms at baseline due to randomization and keeping the study power unchanged as no patient was removed from the analysis [25]. PP analysis is a complementary method to investigate the actual effect of administered treatment strategies throughout the follow-up period. Hence, it only includes the subgroup of patients who completed the RCT trial without significant deviations from the proposed protocol. Patients who dropped out switched the allocation arm of treatment or did not participate for re-evaluation represent the "true" exposure to treatment.

Another proposed model of the protective action of Cannabis is by the activation of the Cannabinoid receptor on hematopoietic cells and enterocytes, as seen in experiments on female C57BL/6 mice [26]. The authors report that THC prevented colitis while CBD offered no significant change in reducing colitis. THC was found to enhance colonic barrier integrity of the large intestine by activating mucus, tight junction and antimicrobial peptide production, and an increase in colonic gram-negative bacteria. Anti-colitic effects of THC were independent of the microbiome. THC acted on both immune cells via CB2 and on enterocytes to attenuate colitis.

The broad activity spectrum of CBD includes antioxidant and anti-inflammatory activity as it is associated with improvement in redox imbalance and inflammation. Evidence shows that CBD reduces the levels of pro-inflammatory cytokines, prevents $\mathrm{T}$ cell proliferation, induces $\mathrm{T}$ cell apoptosis and decreases migration and adhesion of immune cells [27]. In addition, CBD anti-inflammatory activity has been found to be antagonized by both a selective CB2 antagonist and AEA, an endogenous CB2 receptor agonist [28].

In the final analysis, the overall results of the study should be interpreted considering the subjective nature of many parameters and the psychedelic nature of Cannabis. Moreover, the general well-being reported in the patients could be attributed to the symptomatic relief of gastrointestinal-related issues. Since endoscopic healing data and objective inflammatory markers from these patients are not available, there is no actual evidence that indicates that Cannabis modified the disease. Further research is needed to ascertain that Cannabis plays a protective role by modulating the disease and not just alleviating IBD symptoms. 


\section{Future perspective}

Cannabis is still considered a Schedule I drug with high abuse potential and non-usable as medicine by the FDA and the Drug Enforcement Agency (DEA). Even if the initial results show some favourable results, the legal and social implications of the unmonitored use of Cannabis should be allowed only with caution, despite its benefits. Despite reports of improvement in QoL and amelioration of gastrointestinal symptoms, there is no scientific evidence that proves the ability of Cannabis to modify disease objectively. It will be possible by recording the biomarker profiles and endoscopic healing of these patients [29]. There is a need for more in vitro and in vivo studies, and more extensive trials with proper randomization are needed to have a complete understanding of the protective role of Cannabis in IBD. In this scoping review, we have tried to discuss the protective effects of Cannabis in IBD comprehensively [11]. Although promising results including the improvement in general well-being/ Harvey-Bradshaw Index, health perception enhancement $[4.1 \pm 1.43$ to $7 \pm 1.42(p=0.0002)]$, weight gain, CDAI score $<150$, Mayo scores $(4-10)$, and reduction in clinical complications have been found in some studies, its medical use in IBD is still questionable due to the lack of high-quality evidence-based studies. There is also a need to design safer cannabinoid derivatives for use via randomized clinical trials with a larger sample size. This is necessary for determining the appropriate dose, mode of administration, protective effects and side effects of Cannabis before it can be accepted as a possible therapeutic agent for IBD.

\section{Limitations}

First, the high heterogeneity in the findings from the included studies restricted the generalizability of the outcomes from this scoping review. This heterogeneity was reflected in case definition, inclusion criteria, cannabis dosage, mode of administration of Cannabis or cannabinoid, duration of treatment, disease activity indices, and study design of the included studies. Second, the small sample size further reduced the validity and reliability of the reported results. Third, the limited number of RCTs and inclusion of observational studies increased the risk of selection and detection biases that further reduced the strength of our findings.

\section{Conclusions}

This scoping review shows inconclusive results regarding the benefits and harms of Cannabis and cannabidiol in patients with active CD or UC. Only a few studies report the management of active CD and UC with Cannabis or cannabinoids but these lack follow-up data. The findings, however, confirm the improvement in general well-being/Harvey-Bradshaw Index, weight gain, and reduction in clinical complications after cannabis treatment. Future RCTs studies should determine the cannabis treatment parameters and validate its safety and effectiveness in the IBD setting.

\section{Additional Information}

\section{Disclosures}

Conflicts of interest: In compliance with the ICMJE uniform disclosure form, all authors declare the following: Payment/services info: All authors have declared that no financial support was received from any organization for the submitted work. Financial relationships: All authors have declared that they have no financial relationships at present or within the previous three years with any organizations that might have an interest in the submitted work. Other relationships: All authors have declared that there are no other relationships or activities that could appear to have influenced the submitted work.

\section{References}

1. Duerr RH, Taylor KD, Brant SR, et al.: A genome-wide association study identifies IL23R as an inflammatory bowel disease gene. Science. 2006, 314:1461-3. 10.1126/science.1135245

2. de Souza HS, Fiocchi C: Immunopathogenesis of IBD: current state of the art . Nat Rev Gastroenterol Hepatol. 2016, 13:13-27. 10.1038/nrgastro.2015.186

3. Rizzello F, Spisni E, Giovanardi E, et al.: Implications of the westernized diet in the onset and progression of IBD. Nutrients. 2019, 11:1033. 10.3390/nu11051033

4. Martini E, Krug SM, Siegmund B, Neurath MF, Becker C: Mend your fences: the epithelial barrier and its relationship with mucosal immunity in inflammatory bowel disease. Cell Mol Gastroenterol Hepatol. 2017, 4:33-46. 10.1016/j.jcmgh.2017.03.007

5. Khan I, Ullah N, Zha L, et al.: Alteration of gut microbiota in inflammatory bowel disease (IBD): Cause or consequence? IBD treatment targeting the gut microbiome. Pathogens. 2019, 8:126. 10.3390/pathogens8030126

6. Hansen TM, Sabourin BC, Oketola B, Bernstein CN, Singh H, Targownik LE: Cannabis use in persons with inflammatory bowel disease and vulnerability to substance misuse. Inflamm Bowel Dis. 2020, 26:1401-6. 10.1093/ibd/izz272

7. Stallmach A, Hagel S, Bruns T: Adverse effects of biologics used for treating IBD . Best Pract Res Clin Gastroenterol. 2010, 24:167-82.10.1016/j.bpg.2010.01.002

8. Basson AR, Lam M, Cominelli F: Complementary and Alternative Medicine Strategies for Therapeutic Gut Microbiota Modulation in Inflammatory Bowel Disease and their Next-Generation Approaches. Gastroenterol Clin North Am. 2017, 46:689-729. 10.1016/j.gtc.2017.08.002

9. Kafil TS, Nguyen TM, MacDonald JK, Chande N: Cannabis for the treatment of Crohn's disease and ulcerative colitis: evidence from Cochrane reviews. Inflamm Bowel Dis. 2020, 26:502-9. 10.1093/ibd/izz233

10. Hoffenberg EJ, Newman H, Collins C, Tarbell S, Leinwand K: Cannabis and pediatric inflammatory bowel disease: change blossoms a mile high. J Pediatr Gastroenterol Nutr. 2017, 64:265-71. 
10.1097/MPG.0000000000001393

11. Ahmed W, Katz S: Therapeutic use of cannabis in inflammatory bowel disease . Gastroenterol Hepatol. 2016, 12:668-79.

12. Kerlin AM, Long M, Kappelman M, Martin C, Sandler RS: Profiles of patients who use marijuana for inflammatory bowel disease. Dig Dis Sci. 2018, 63:1600-4. 10.1007/s10620-018-5040-5

13. Naftali T, Lev LB, Yablecovitch D, et al.: Treatment of Crohn's disease with Cannabis: an observational study. Israel Med Assoc J. 2011, 13:455-8.

14. Lahat A, Lang A, Ben-Horin S: Impact of cannabis treatment on the quality of life, weight and clinical disease activity in inflammatory bowel disease patients: a pilot prospective study. Digestion. 2012, 85:1-8. $10.1159 / 000332079$

15. Naftali T, Bar-Lev Schleider L, Dotan I, Lansky EP, Sklerovsky Benjaminov F, Konikoff FM: Cannabis induces a clinical response in patients with Crohn's disease: a prospective placebo-controlled study. Clin Gastroenterol Hepatol. 2013, 11:1276-1280.e1. 10.1016/j.cgh.2013.04.034

16. Naftali T, Mechulam R, Marii A, et al.: Low-dose cannabidiol is safe but not effective in the treatment for Crohn's disease, a randomized controlled trial. Dig Dis Sci. 2017, 62:1615-20. 10.1007/s10620-017-4540-z

17. Irving PM, Iqbal T, Nwokolo C, et al.: A randomized, double-blind, placebo-controlled, parallel-group, pilot study of cannabidiol-rich botanical extract in the symptomatic treatment of ulcerative colitis. Inflamm Bowel Dis. 2018, 24:714-24. 10.1093/ibd/izy002

18. Mbachi C, Attar B, Wang Y, et al.: Association between cannabis use and complications related to Crohn's disease: a retrospective cohort study. Dig Dis Sci. 2019, 64:2939-44. 10.1007/s10620-019-05556-Z

19. Howlett AC, Barth F, Bonner TI, et al.: International Union of Pharmacology. XXVII. Classification of cannabinoid receptors. Pharmacol Rev. 2002, 54:161-202. 10.1124/pr.54.2.161

20. Evans FJ: Cannabinoids: the separation of central from peripheral effects on a structural basis. . Planta Med. 1991, 57:S60-7. 10.1055/s-2006-960231

21. Percie du Sert N, Ho WS, Rudd JA, Andrews PL: Cannabinoid-induced reduction in antral pacemaker frequency: a telemetric study in the ferret. Neurogastroenterol Motil. 2010, 22:1257-66, e324. 10.1111/j.1365-2982.2010.01581.x

22. Perisetti A, Rimu AH, Khan SA, Bansal P, Goyal H: Role of cannabis in inflammatory bowel diseases . Ann Gastroenterol. 2020, 33:134-44. 10.20524/aog.2020.0452

23. Weiss A, Friedenberg F: Patterns of cannabis use in patients with inflammatory bowel disease: a population based analysis. Drug Alcohol Depend. 2015, 156:84-9. 10.1016/j.drugalcdep.2015.08.035

24. Naftali T, Mechulam R, Lev LB, Konikoff FM: Cannabis for inflammatory bowel disease. Dig Dis. 2014, 32:468-74. 10.1159/000358155

25. Tripepi G, Chesnaye NC, Dekker FW, Zoccali C, Jager KJ: Intention to treat and per protocol analysis in clinical trials. Nephrology. 2020, 25:513-7. 10.1111/nep.13709

26. Becker W, Alrafas HR, Busbee PB, et al.: Cannabinoid receptor activation on haematopoietic cells and enterocytes protects against colitis. J Crohns Colitis. 2021, 15:1032-48. 10.1093/ecco-jcc/jjaa253

27. Jean-Gilles L, Braitch M, Latif ML, et al.: Effects of pro-inflammatory cytokines on cannabinoid CB1 and CB2 receptors in immune cells. Acta Physiol. 2015, 214:63-74. 10.1111/apha.12474

28. Petrosino S, Verde R, Vaia M, Allarà M, Iuvone T, Di Marzo V: Anti-inflammatory properties of cannabidiol, a nonpsychotropic cannabinoid, in experimental allergic contact dermatitis. J Pharmacol Exp Ther. 2018, 365:652-63. 10.1124/jpet.117.244368

29. Swaminath A, Berlin EP, Cheifetz A, et al.: The role of cannabis in the management of inflammatory bowel disease: a review of clinical, scientific, and regulatory information commissioned by the Crohn's and colitis foundation. Inflamm Bowel Dis. 2019, 25:427-35. 10.1093/ibd/izy319 